\title{
Originals
}

\section{Human interleukin-1 $\beta$ induced stimulation of insulin release from rat pancreatic islets is accompanied by an increase in mitochondrial oxidative events}

\author{
D. L. Eizirik and S. Sandler \\ Department of Medical Cell Biology, Uppsala University, Uppsala, Sweden
}

\begin{abstract}
Summary. Acute exposure of pancreatic islets to interleukin$1 \beta$ results in an increase in insulin release, while an extension of the exposure time induces a functional suppression and eventually, destruction of the B-cells. We have recently suggested that the interleukin- $1 \beta$ induced inhibition of islet function is mediated through an impairment in oxidative metabolism. The aim of the current study was to investigate if the acute, stimulatory effects of interleukin-1 $\beta$ on islet function could also be related to changes in the substrate metabolism. For this purpose, rat islets were exposed for $90-120 \mathrm{~min}$ to $30 \mathrm{pmol} / 1$ human recombinant interleukin-1 $\beta$ (biological activity of $2.5 \mathrm{U} / \mathrm{ml}$ ) and their function and metabolism characterized during this period. The cytokine did not increase insulin release in the presence of 1.7 or $5.5 \mathrm{mmol} / 1$ glucose but in both the presence of $16.7 \mathrm{mmol} / 1$ glucose or $10 \mathrm{mmol} / 1 \mathrm{leu}-$ cine $+2 \mathrm{mmol} / 1$ glutamine there was a $50 \%$ increase in insulin release. Interleukin- $1 \beta$ exposure increased the oxidation of D-[U- $\left.{ }^{14} \mathrm{C}\right]$ glucose at $5.5 \mathrm{mmol} / \mathrm{l}$ glucose by $25 \%$ and at $16.7 \mathrm{mmol} / 1$ glucose by $60 \%$. Carbohydrate and amino acid metabolism were further examined in the presence of $\mathrm{D}-\left[5-{ }^{3} \mathrm{H}\right]$ glucose, D-[6- $\left.{ }^{14} \mathrm{C}\right] g l u c o s e, \quad\left[1-{ }^{14} \mathrm{C}\right] p y r u v a t e, \quad \mathrm{~L}-\left[\mathrm{U}-{ }^{14} \mathrm{C}\right] \mathrm{glu}-$ tamine, $\mathrm{L}-\left[\mathrm{U}-{ }^{14} \mathrm{C}\right]$ leucine and $\mathrm{L}-\left[1-{ }^{14} \mathrm{C}\right]$ leucine. There was no
\end{abstract}

difference between control islets and interleukin- $1 \beta$ exposed islets in terms of D-[5-3 $\mathrm{H}]$ glucose utilization or $\left[1-{ }^{14} \mathrm{C}\right]$ pyruvate decarboxylation, but the oxidation of $\mathrm{D}-\left[6-{ }^{14} \mathrm{C}\right] \mathrm{glucose}$ was increased by $64 \%$ in the interleukin- $1 \beta$ exposed islets. There was also an interleukin- $1 \beta$ induced $45-60 \%$ increase in the decarboxylation of $\mathrm{L}-\left[1-{ }^{14} \mathrm{C}\right]$ leucine and oxidation of $\mathrm{L}-\left[\mathrm{U}-{ }^{14} \mathrm{C}\right] \mathrm{leu}-$ cine and $\mathrm{L}-\left[\mathrm{U}-{ }^{14} \mathrm{C}\right] \mathrm{glutamine}$, all intramitochrondrial events. The stimulation of insulin release by interleukin-1 $\beta$ in the presence of $16.7 \mathrm{mmol} / 1$ glucose was abolished in islets incubated in $\mathrm{Ca}^{2+}$ depleted medium, but the rate of $\mathrm{D}-\left[6-{ }^{14} \mathrm{C}\right]$ glucose oxidation remained elevated $(47 \%$ increase at $16.7 \mathrm{mmol} / 1$ glucose). These data indicate an increase in substrate metabolism at the mitochondrial level during acute ex-

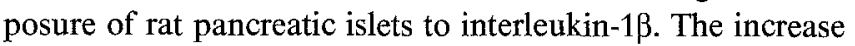
in oxidative events can explain the observed interleukin-1 $\beta$ induced increase in insulin release during glucose stimulation. Furthermore, these findings raise the possibility that mitochondria are primary targets of interleukin-1 $\beta$ action in the B-cells.

Key words: Pancreatic islets, insulin release, interleukin-1 $\beta$, glucose metabolism, amino acid metabolism.
Interleukin-1 (IL-1) is a polypeptide hormone produced by macrophages and other cell types. IL-1 has several biological effects, ranging from activation of lymphocytes to induction of diverse components of the host acute-phase response to infection and injury [1]. In addition, IL-1 has been found to affect the insulin secreting B-cells of the pancreas. Acute in vitro exposure of pancreatic islets to IL-1 increases the biosynthesis and release of insulin [2-6]. When the exposure time is prolonged, IL-1 induces suppression of insulin release and destruction of B-cells [7-9]. Based on these observations, it has been suggested that IL-1 may be one of the main mediators of the immunologically induced B-cell destruction in Type 1 (insulin-dependent) diabetes mellitus $[10,11]$.
The mechanisms by which IL-1 initially stimulate and subsequently suppress the B-cells are still unknown. Previous studies in rat islets, dealing with the suppressive phase of interleukin-1 $\beta$ (IL-1 $\beta$ ) action (48 h of exposure), showed that the cytokine impaired the oxidation of D-[U- $\left.{ }^{14} \mathrm{C}\right] \mathrm{glucose}[9,12]$. Subsequent experiments suggested that this impairment was the consequence of a defective mitochondrial oxidation of glucose, while the glycolytic pathway, as evaluated by the utilization of $\mathrm{D}-\left[5-{ }^{3} \mathrm{H}\right] \mathrm{glucose}$, remained intact [13, 14]. After $48 \mathrm{~h}$ exposure to IL-1, the modifications in substrate metabolism can, however, be the result of either a direct IL-1 action and/or an adaptative response of the injured B-cells. Indeed, islets maintained in culture after exposure to another B-cell toxin, strep- 


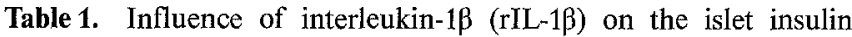
release in response to different secretagogues

\begin{tabular}{|c|c|c|c|}
\hline \multirow[t]{2}{*}{$\begin{array}{l}\text { rIL-1 } \beta \\
(\mathrm{pmol} / 1)\end{array}$} & \multirow[t]{2}{*}{$\begin{array}{l}\text { Secretagogues }(2 \mathrm{nd} \mathrm{h}) \\
(\mathrm{mmol} / \mathrm{l})\end{array}$} & \multicolumn{2}{|c|}{$\begin{array}{l}\text { Insulin release } \\
(\mathrm{ng} \cdot 10 \text { islets } \\
\left.-1.60 \mathrm{~min}^{-1}\right)\end{array}$} \\
\hline & & $\begin{array}{l}1 \mathrm{st} \mathrm{h} \\
(1.7 \mathrm{mmol} / 1 \\
\text { glucose })\end{array}$ & $\begin{array}{l}\text { 2nd h } \\
\text { (different } \\
\text { secretagogues) }\end{array}$ \\
\hline 0 & Glucose 16.7 & $3.2 \pm 0.6$ & $19.8 \pm 1.4$ \\
\hline 30 & Glucose 16.7 & $3.9 \pm 0.8$ & $29.1 \pm 2.8^{b}$ \\
\hline 0 & Leucine $10+$ Glutamine 2 & $2.5 \pm 0.4$ & $16.1 \pm 2.7$ \\
\hline 30 & Leucine $10+$ Glutamine 2 & $3.4 \pm 0.3$ & $23.7 \pm 2.2^{\mathrm{a}}$ \\
\hline
\end{tabular}

Insulin release was measured by incubating islets in groups of 10 (in triplicate) in Krebs-Ringer bicarbonate buffer containing $1.7 \mathrm{mmol} / 1$ glucose and, when indicated, $30 \mathrm{pmol} / 1 \mathrm{rIL}-1 \beta$. During the $2 \mathrm{nd} \mathrm{h}$, the medium was exchanged for medium supplemented with the different secretagogues, with or without the addition of rIL-1 $\beta$. Mean values \pm SEM are derived from 6 experiments. Significance is given for a chance difference vs the respective control group. ${ }^{\mathrm{a}} p<0.05 ;{ }^{\mathrm{b}} p<0.01$

Table 2. D-Glucose and pyruvate metabolism in the presence or absence of interleukin- $1 \beta(\mathrm{rIL}-1 \beta ; 30 \mathrm{pmol} / 1)$

\begin{tabular}{|c|c|c|}
\hline \multirow[t]{2}{*}{ Nutrients (mmol/l) } & \multicolumn{2}{|c|}{ 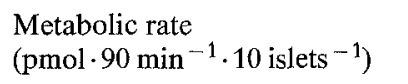 } \\
\hline & Control & rIL-1 $\beta$ \\
\hline $\mathrm{D}-\left[\mathrm{U}-{ }^{14} \mathrm{C}\right]$ Glucose $(1.7)$ & $78 \pm 19$ & $81 \pm 16$ \\
\hline D-[U- $\left.{ }^{14} \mathrm{C}\right]$ Glucose $(5.5)$ & $255 \pm 15$ & $319 \pm 16^{\mathrm{a}}$ \\
\hline D-[U- ${ }^{14}$ C]Glucose $(16.7)$ & $453 \pm 51$ & $705 \pm 113^{b}$ \\
\hline $\mathrm{D}-\left[5-^{3} \mathrm{H}\right]$ Glucose $(16.7)$ & $595 \pm 120$ & $534 \pm 63$ \\
\hline D-[6- $\left.{ }^{-14} \mathrm{C}\right]$ Glucose $(16.7)$ & $223 \pm 26$ & $356 \pm 24^{b}$ \\
\hline$\left[1-{ }^{14} \mathrm{C}\right]$ Pyruvate (5.0) & $544 \pm 77$ & $556 \pm 98$ \\
\hline
\end{tabular}

The oxidation of D-glucose and pyruvate was measured in triplicate groups of 20 islets each. Mean values \pm SEM are derived from 5-6 experiments. Significance is given for a chance difference vs the respective control group. ${ }^{\mathrm{a}} p<0.05 ;{ }^{\mathrm{b}} p<0.01$

tozotocin, also present a selective impairment in the mitochondrial metabolism of glucose [15].

Thus, in order to further explore the mechanisms by which IL-1 affect B-cell function, the current experiments were designed to study the functional and metabolic responses of rat pancreatic islets during the first few hours of exposure to the cytokine.

\section{Materials and methods}

Male Sprague-Dawley rats 3-4 months old, belonging to a local stock maintained at the Biomedical Center, Uppsala, Sweden, were utilized for islet isolation. The islets were isolated from the collagenasedigested pancreas with the aid of Ficoll gradients [16]. Groups of $150-200$ islets were maintained free-floating in culture medium RPMI 1640 (Flow Laboratories, Irvine, UK) containing 10\% (volume/volume) calf serum (National Bacteriological Laboratory, Stockholm, Sweden) antibiotics and $11.1 \mathrm{mmol} / 1$ glucose [17]. The culture medium was changed on days 2 and 4. After 5-6 days in culture, $30 \mathrm{pmol} / 1 \mathrm{rIL}-1 \beta$ was added to the medium and after $15 \mathrm{~min}$ the islets were harvested and used for the functional and metabolic studies described below, in the presence of the cytokine. Recombinant

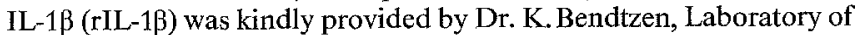
Medical Immunology, Rigshospitalet, Copenhagen, Denmark. A bi- ological assay showed that $30 \mathrm{pmol} / 1$ of the cytokine had a biological activity of approximately $2.5 \mathrm{U} / \mathrm{ml}$ (compared with an interim international standard IL-1B preparation, NIBSC, London, UK). The activity of the cytokine was confirmed using both the mouse costimulatory assay and the EL 4 murine T cell line [18]. The concentration of rIL-1 $\beta$ utilized was selected following a previous dose-response study [19], in which rIL-1 $\beta$ in the concentration range of $3-3000 \mathrm{pmol} / 1$, induced a similar $30-50 \%$ increase in insulin release at $20 \mathrm{mmol} / 1 \mathrm{glu}$ cose, during acute $(2 \mathrm{~h})$ exposure. Furthermore, $30-60$ pmol/1 1 rIL-1 $\beta$ induce a reproducible suppression of $\beta$-cell function after $48 \mathrm{~h}$ exposure, without causing severe necrotic changes in the islets $[13,20]$.

Insulin release was studied in triplicate groups of 10 islets, as previously described [9]. The islets were placed in sealed glass vials [21], containing $0.25 \mathrm{ml}$ of Krebs-Ringer bicarbonate buffer [22], supplemented with $10 \mathrm{mmol} / 1$ Hepes and $2 \mathrm{mg} / \mathrm{ml}$ bovine serum albumin (hereafter designated KRBH buffer) and when indicated $30 \mathrm{pmol} / 1 \mathrm{rIL}-1 \beta$. In some experiments the KRBH medium was prepared without the addition of $\mathrm{Ca}^{2+}$, and supplemented with $0.25 \mathrm{mmol} / 1$ ethyleneglycol-bis-( $\beta$-amino-ethyl ether) $\mathrm{N}, \mathrm{N}$-tetraacetic acid (EGTA). During the first hour of incubation the medium contained $1.7 \mathrm{mmol} / 1$ glucose. The medium was then gently removed and replaced during the second hour by $\mathrm{KRBH}$ containing either 5.6 or $16.7 \mathrm{mmol} / 1$ glucose or $10 \mathrm{mmol} / 1$ leucine $+2 \mathrm{mmol} / 1$ glutamine. The insulin concentration in the incubation medium was determined by RIA [23].

For the studies of glucose, pyruvate, leucine and glutamine metabolism radioactive precursors were obtained from the following sources: D-[U- $\left.{ }^{14} \mathrm{C}\right] \mathrm{glucose} \quad(270 \mathrm{mCi} / \mathrm{mmol}), \quad$ D- $\left[5-{ }^{3} \mathrm{H}\right] \mathrm{glucose}$ (21.1 Ci/mmol), D- $\left[6-{ }^{-14} \mathrm{C}\right] \mathrm{glucose}(55 \mathrm{mCi} / \mathrm{mmol}), \quad$ L-[U- $\left.{ }^{14} \mathrm{C}\right] \mathrm{glu}-$ tamine $(205 \mathrm{mCi} / \mathrm{mmol})$, L- $\left[\mathrm{U}^{14} \mathrm{C}\right]$ leucine $(342 \mathrm{mCi} / \mathrm{mmol})$ and $\mathrm{L}-\left[1{ }^{14} \mathrm{C}\right]$ leucine $(55 \mathrm{mCi} / \mathrm{mmol})$ from Amersham International (Amersham, UK) and $\left[1-{ }^{14} \mathrm{C}\right]$ pyruvic acid $(13.0 \mathrm{mCi} / \mathrm{mmol})$ from New England Nuclear (Boston, Mass, USA).

In order to study the oxidation of either D-[U- $\left.{ }^{14} \mathrm{C}\right] \mathrm{glucose}$, D- $\left[6-{ }^{14} \mathrm{C}\right]$ glucose, $\mathrm{L}-\left[\mathrm{U}-{ }^{14} \mathrm{C}\right] \mathrm{glutamine}, \mathrm{L}-\left[\mathrm{U}-{ }^{14} \mathrm{C}\right]$ leucine, L- $\left[1-{ }^{14} \mathrm{C}\right]$ leucine or $\left[1-{ }^{14} \mathrm{C}\right]$ pyruvate, triplicate groups of 20 islets each were transferred to sealed glass vials [21] containing the labelled substrates and non-radioactive glucose, pyruvate, glutamine or leucine at the final concentrations given in the tables. The substrate oxidation was measured as previously described [24].

The utilization of glucose was determined as the formation of ${ }^{3} \mathrm{H}_{2} \mathrm{O}$ from D-[5- $\left.{ }^{3} \mathrm{H}\right]$ glucose. Triplicate groups of 20 islets each were incubated in $15 \mu \mathrm{l}$ of $\mathrm{KRBH}$ buffer and non-radioactive glucose to a final concentration of $16.7 \mathrm{mmol} / 1$ glucose, and the glucose utilization measured as described in detail elsewhere [25]. In these and the above described experiments, the mean of the triplicate experiments from one islet isolation was considererd as one observation.

\section{Statistical analysis}

Data were computed as means \pm SEM and compared using Student's $t$-test for paired samples.

\section{Results}

Short-term exposure of islets to rIL-1 $\beta$ did not stimulate insulin release at $1.7 \mathrm{mmol} / 1$ glucose (Table 1 ). However, in the presence of either $16.7 \mathrm{mmol} / 1$ glucose or $10 \mathrm{mmol} / 1$ leucine $+2 \mathrm{mmol} / 1$ glutamine the cytokine augmented the insulin release by approximately $50 \%$. In a separate series of experiments, the insulin release in response to $5.5 \mathrm{mmol} / 1$ glucose was also studied. Again there was no stimulation of insulin release by rIL-1 $\beta$ at $1.7 \mathrm{mmol} / 1$ glucose (control, $8.4 \pm 0.8 \mathrm{ng} \cdot 10$ islets $^{-1}$ $.60 \mathrm{~min}^{-1} ; \quad$ rIL1ß exposed, $8.4 \pm 0.9 \mathrm{ng} \cdot 10$ islets $^{-1}$ 
$.60 \min ^{-1}, n=6$ in both groups). During the second hour of incubation, in the presence of $5.5 \mathrm{mmol} / 1 \mathrm{glu}-$ cose, there was also no stimulatory effect of the cytokine (control, $7.5 \pm 1.1 \mathrm{ng} \cdot 10$ islets $^{-1} \cdot 60 \mathrm{~min}^{-1} ; \mathrm{rIL}-1 \beta$ exposed, $6.3 \pm 1.3 \mathrm{ng} \cdot 10$ islets $^{-1} .60 \mathrm{~min}^{-1}$ ).

In good agreement with the lack of stimulation of insulin release by rIL- $1 \beta$ at $1.7 \mathrm{mmol} / 1$ glucose, the oxidation of $\mathrm{D}-\left[\mathrm{U}-{ }^{14} \mathrm{C}\right] \mathrm{glucose}$ at this glucose concentration was unaffected by the cytokine (Table 2). However, at $5.5 \mathrm{mmol} / 1$ glucose there was a $25 \%$ increase in D-[U$\mathrm{C}^{14} \mathrm{glucose}$ oxidation and at $16.7 \mathrm{mmol} / 1$ glucose there was a $54 \%$ increase. Further characterization of the glucose metabolism in the presence of $\mathrm{rIL}-1 \beta$ showed an unchanged $\mathrm{D}-\left[5-{ }^{3} \mathrm{H}\right]$ glucose utilization and $\left[1{ }^{14} \mathrm{C}\right] \mathrm{pyru}-$ vate decarboxylation as compared to control islets, but a $64 \%$ increase in the $\mathrm{D}-\left[6-{ }^{14} \mathrm{C}\right]$ glucose oxidation (Table 2). To test if the observed increase in glucose oxidation induced by rIL-1 $\beta$ could be a consequence, rather than a cause, of the increase in insulin release, we studied both parameters in a $\mathrm{Ca}^{2+}$ free KRBH buffer, supplemented with $0.25 \mathrm{mmol} / 1$ EGTA. The depletion of $\mathrm{Ca}^{2+}$ abolished the rIL-1 $\beta$ induced increase in insulin release at $16.7 \mathrm{mmol} / 1$ glucose (Table 3 ). Indeed, both control and rIL-1 $\beta$ exposed islets failed to increase the insulin release in response to glucose in the absence of $\mathrm{Ca}^{2+}$. There was however, still a $47 \%$ increase in $\mathrm{D}-\left[6{ }^{14} \mathrm{C}\right] \mathrm{glucose}$ oxidation in the presence of rIL-1B.

The oxidation of L-[U $\left.-{ }^{14} \mathrm{C}\right] g l u t a m i n e ~ a n d ~ L-\left[U-1{ }^{14} \mathrm{C}\right]$ leucine, as well as the decarboxylation of $\mathrm{L}-\left[1-{ }^{14} \mathrm{C}\right]$ leucine, were all increased by $45-60 \%$ in the presence of rIL-1 $\beta$ (Table 4).

\section{Discussion}

The present results confirm that acute exposure of pancreatic islets to rIL-1 $\beta$ augments the insulin release in the presence of stimulatory concentrations of glucose, and extend these findings to stimulation of insulin release also in the presence of leucine plus glutamine. At lower concentration of glucose $(1.7$ and $5.5 \mathrm{mmol} / \mathrm{l})$, rIL-1 $\beta$ did not induce any increase in insulin release. Previous reports have shown that IL-1 could acutely increase glucose-induced insulin release of isolated islets [2-6] and in the perfused rat pancreas [26]. A similar potentiation by IL-1 was observed in the presence of glyceraldehyde and $\alpha$-ketoisocaproate [6], but was absent at low glucose concentratiaons $[6,26]$. The combined data suggest that IL-1 potentiates nutrient-induced insulin release, but does not increase the insulin release at non-stimulatory levels of the insulin secretagogues.

The catabolism of glucose and amino acids in the Bcells represents a critical step in the regulation of insulin secretion [27]. An acute stimulation of these metabolic pathways by IL- 1 may explain the observed increase in insulin release in response to glucose and leucine. Indeed, in the presence of rIL-1 $\beta$ there was a significant in-
Table 3. Influence of interleukin-1 $\beta$ (rIL-1 $; 30 \mathrm{pmol} / \mathrm{l}$ ) on islet glucose-induced insulin release and glucose metabolism in $\mathrm{Ca}^{2+} \mathrm{de}-$ pleted medium

\begin{tabular}{|c|c|c|c|}
\hline Variable under study & $\begin{array}{l}\text { Glucose } \\
(\mathrm{mmol} / \mathrm{l})\end{array}$ & Control & rIL-1 $\beta$ \\
\hline $\begin{array}{l}\text { Insulin release } \\
\left(\mathrm{ng} \cdot 10 \text { islets }{ }^{-1} \cdot 60 \mathrm{~min}^{-1}\right)\end{array}$ & 1.7 & $5.4 \pm 0.9$ & $3.2 \pm 0.4$ \\
\hline $\begin{array}{l}\text { Insulin release } \\
\left(\mathrm{ng} \cdot 10 \text { islets }^{-1} \cdot 60 \mathrm{~min}^{-1}\right)\end{array}$ & 16.7 & $5.9 \pm 1.4$ & $3.7 \pm 0.8$ \\
\hline $\begin{array}{l}\left.\text { D-[6- }{ }^{-14} \mathrm{C}\right] \text { glucose oxidation } \\
\left(\mathrm{pmol} .90 \mathrm{~min}^{-1} \cdot 10 \text { islets }\right. \\
-1\end{array}$ & 16.7 & $122 \pm 15$ & $166 \pm 17^{a}$ \\
\hline
\end{tabular}

Insulin release and $\mathrm{D}-\left[6-{ }^{14} \mathrm{C}\right]$ glucose oxidation were measured as described in Tables 1 and 2, respectively, except for the omission of $\mathrm{Ca}^{2+}$ in the Krebs-Ringer bicarbonate buffer and addition of $0.25 \mathrm{mmol} / 1$ EGTA. Mean values \pm SEM are derived from 6-8 experiments. Significance is given for a chance difference vs the respective control group. ${ }^{\mathrm{a}} p<0.05$

Table 4. L-leucine and L-glutamine metabolism in the presence of interleukin-1 $\beta$ (rIL-1 $\beta ; 30 \mathrm{pmol} / \mathrm{l}$ )

\begin{tabular}{|c|c|c|}
\hline \multirow[t]{2}{*}{ Nutrients (mmol/1) } & \multicolumn{2}{|c|}{ Metabolic rate (pmol. $90 \mathrm{~min}^{-1} \cdot 10$ islets ${ }^{-1}$ ) } \\
\hline & Control & rIL-1 $\beta$ \\
\hline $\begin{array}{l}\text { L-[U- }{ }^{14} \text { C]Glutamine } \\
(2.0)+\text { Leucine }(10)\end{array}$ & $354 \pm 53$ & $498 \pm 56^{\mathrm{b}}$ \\
\hline $\begin{array}{l}\text { L- }\left[\mathrm{U}-{ }^{14} \mathrm{C}\right] \text { Leucine }(10) \\
+ \text { Glutamine }(2.0)\end{array}$ & $128 \pm 11$ & $187 \pm 15^{\mathrm{a}}$ \\
\hline $\begin{array}{l}\text { L-[1-14 C]Leucine (10) } \\
\text { + Glutamine }(2.0)\end{array}$ & $218 \pm 38$ & $315 \pm 33^{a}$ \\
\hline
\end{tabular}

The oxidation of L-glutamine and L-leucine was measured in triplicate groups of 20 islets each. Mean values \pm SEM are derived from 5-8 experiments. Significance is given for a chance difference vs the respective control group. ${ }^{\mathrm{a}} p<0.01{ }^{\mathrm{b}} p<0.001$

crease in D-[U- ${ }^{14}$ C]glucose catabolism, at $16.7 \mathrm{mmol} / \mathrm{l}$ glucose. This increase was mainly due to an augmented mitochondrial oxidation of glucose, as judged by the increased D- $\left[6-{ }^{14} \mathrm{C}\right] \mathrm{glucose}$ oxidation in the presence of rIL-1 $\beta$. However, there were no changes in either the glycolytic pathway or in the conversion of pyruvate to acetyl-CoA, as evidenced by the D- $\left[5-{ }^{3} \mathrm{H}\right] \mathrm{glucose}$ utilization and $\left[1-{ }^{14} \mathrm{C}\right]$ pyruvate decarboxylation experiments. It has previously been suggested that B-cells exhibit a dissociated regulation of glycolytic and mitochondrial oxidative events, with a preferential activation of the latter in the presence of stimulatory concentrations of hexoses $[15,28,29]$. The present study reinforces this concept and suggests that rIL-1 $\beta$ potentiates the selective stimulation of mitochondrial events. It is thus conceivable that the increase in insulin release induced by rIL-1 $\beta$ can be due to an increased substrate metabolism at the Krebs cycle level.

It is noteworthy that at $5.5 \mathrm{mmol} / 1$ glucose there was a dissociation between a minor rIL-1 $\beta$-induced stimulation of glucose oxidation and a lack of effect of the cytokine on insulin release. It may be that at this non-stimulatory concentration of glucose, the slight in- 
crease in substrate metabolism was not sufficient to trigger insulin secretion. It should also be noted that other factors not directly coupled to substrate metabolism can contribute to the IL-1-induced stimulation of insulin release. Indeed, recent data by Zawalich und co-workers suggest that IL-1 can increase phosphoinositide hydrolysis $[6,30]$. However, it is not clear if this process is mediated by the classical inositol triphosphate formation, resulting from a receptor-agonist interaction [31], or is secondary to other cellular events induced by IL-1.

Another interpretation of the current findings must also be considered. The release of insulin is a major energy requiring process in the B-cells, and it has been recently shown that an increased demand of ATP can exert a positive feedback control on the mitochondria [29]. To test this possibility, the effects of rIL-1 $1 \beta$ on insulin release and D- $\left[6-{ }^{14} \mathrm{C}\right] \mathrm{glucose}$ oxidation were studied in a medium depleted of $\mathrm{Ca}^{2+}$. In this situation, there was no stimulation of insulin release, and the glucose oxidation was decreased, as compared to data observed in the presence of $\mathrm{Ca}^{2+}$. The decrease in D-[6${ }^{14} \mathrm{Clglucose}$ oxidation in the absence of $\mathrm{Ca}^{2+}$ is in good agreement with recent findings by Malaisse and Sener [29]. Although a primary effect of $\mathrm{Ca}^{2+}$ deprivation upon the activity of mitochondrial enzymes can not be excluded, it has been suggested that this finding reflects a decreased energy demand in the B-cell due to decreased insulin release [29]. However, even during incubation in the $\mathrm{Ca}^{2+}$ depleted medium rIL-1 $\beta$ was able to induce an increase in D-[6- $\left.{ }^{14} \mathrm{C}\right]$ glucose oxidation, as compared to control islets. These findings emphasize the possibility that the observed increase in glucose oxidation was the cause rather than the consequence of the increased insulin release.

The process of leucine-stimulated insulin release depends on an increase in catabolic fluxes in the islets, via both a leucine-stimulated glutamate catabolism [32] and the catabolism of leucine itself [33]. As suggested by the observed increase in $\left[1-{ }^{14} \mathrm{C}\right]$ leucine decarboxylation, [U$\left.{ }^{14} \mathrm{C}\right]$ leucine oxidation and $\left[\mathrm{U}-{ }^{14} \mathrm{C}\right] \mathrm{glutamine}$ oxidation, rIL-1 $\beta$ potentiated leucine-induced insulin release by both of the above described processes. The observed increase in $\left[1-{ }^{14} \mathrm{C}\right]$ leucine decarboxylation suggests that other intramitochondrial reactions, besides that of the Krebs cycle, may also be stimulated by the cytokine.

When islets are exposed to rIL-1 over a longer time period, there is suppression of insulin release and damage of B-cells [7-9]. This inhibition of insulin release is accompanied by an inhibited mitochondrial metabolism of glucose $[13,14,20]$. The present observations, that an altered mitochondrial handling of substrates is already observed in the first $2 \mathrm{~h}$ of exposure to IL-1, raises the intriguing possibility that mitochondria are primary targets of the IL-1 $\beta$ action in the B-cells. How and why this early phase of stimulation of the mitochondrial metabolism will later proceed to an inhibited state remains, however, to be clarified.
Acknowledgements. We thank Ms. E. Forsbeck and Ms. A. Nordin for their technical assistance and Ms. A.Snellman for careful typing of the manuscript. This work was supported by grants from the Swedish Medical Research Council (12X-109; 12X-8273), the Swedish Diabetes Association, the Swedish Society of Medicine, the Nordic Insulin Fund, the Hoechst Diabetes Foundation, the Juvenile Diabetes Foundation International, the Ragnar and Torsten Söderberg Foundation, the Family Ernfors Fund, A age Louis Hansems Minden Fond and Magnus Bergvalls Stiftelse. Dr. Eizirik is the recipient of a Fellowship Award from the Juvenile Diabetes Foundation International.

\section{References}

1. Bendtzen K (1988) Interleukin 1, interleukin 6 and tumor necrosis factor in infection, inflammation and immunity. Immunol Lett 19: 189-192

2. Zawalich WS, Diaz VA (1986) Interleukin 1 inhibits insulin secretion from isolated perifused rat islets. Diabetes 35: 1119-1123

3. Spinas GA, Hansen BS, Linde S, Kastern W, Mølvig J, MandrupPoulsen T, Dinarello CA, Nielsen JH, Nerup J (1987) Interleukin 1 dose-dependently affects the biosynthesis of (pro)insulin in isolated rat islets of Langerhans. Diabetologia 30: 474-480

4. Comens PG, Wolf BA, Unanue ER, Lacy PE, McDaniel M (1987) Interleukin 1 is potent modulator of insulin secretion from isolated rat islets of Langerhans. Diabetes 36: 963-970

5. Spinas GA, Palmer JP, Mandrup-Poulsen T, Andersen H, Nielsen JH, Nerup J (1988) The bimodal effect of interleukin 1 on rat pancreatic beta-cells-stimulation followed by inhibition-depends upon dose, duration of exposure, and ambient glucose concentration. Acta Endocrinol 119: 307-311

6. Zawalich WS, Zawalich KC (1989) Interleukin 1 is a potent stimulator of islet insulin secretion and phosphoinositide hydrolysis. Am J Physiol 256: E19-E24

7. Bendtzen K, Mandrup-Poulsen T, Dinarello CA, Nerup J, Nielsen JH, Svenson M (1986) Cytotoxicity of human pI7 interleukin1 for pancreatic islets of Langerhans. Science 232: 1545-1547

8. Mandrup-Poulsen T, Bendtzen K, Nerup J, Dinarello CA, Svenson $M$, Nielsen JH (1986) Affinity-purified human interleukin- 1 is cytotoxic to isolated islets of Langerhans. Diabetologia 29: 63-67

9. Sandler S, Andersson A, Hellerström C (1987) Inhibitory effects of interleukin 1 on insulin secretion, insulin biosynthesis, and oxidative metabolism of isolated pancreatic islets. Endocrinology 121: $1424-1431$

10. Nerup J, Mandrup-Poulsen T, Mølvig J, Helqvist S, Wogensen L, Egeberg J (1988) Mechanisms of pancreatic $\beta$-cell destruction in type 1 diabetes. Diabetes Care 11 [Suppl 1]: 16-23

11. Bendtzen K (1989) Immune hormones (cytokines): pathogenic role in autoimmune rheumatic and endocrine diseases. Autoimmunity 2: $177-189$

12. Eizirik DL, Strandell E, Bendtzen K, Sandler S (1988) Functional characteristics of rat pancreatic islets maintained in culture after exposure to human interleukin 1. Diabetes 37:916-919

13. Eizirik DL (1988) Interleukin-1 induced impairment in pancreatic islet oxidative metabolism of glucose is potentiated by tumour necrosis factor. Acta Endocrinol 119: 321-325

14. Sandler S, Bendtzen K, Borg LAH, Eizirik DL, Strandell E, Welsh N (1989) Studies on the mechanisms causing inhibition of insulin secretion in rat pancreatic islets exposed to human interleukin- $1 \beta$ indicate a perturbation in the mitochondrial function. Endocrinology 124: 1492-1501

15. Eizirik DL, Sandler S, Sener A, Malaisse WJ (1988) Defective catabolism of D-glucose and L-glutamine in mouse pancreatic islets maintained in culture after streptozotocin exposure. Endocrinology 123: 1001-1007

16. Lernmark $\AA$, Nathans A, Steiner DF (1976) Preparation and characterization of plasma membrane-enriched fractions from pancreatic islets. J Cell Biol 17: 606-623 
17. Andersson A (1978) Isolated mouse pancreatic islets in culture: effects of serum and different culture media on the insulin production of the islets. Diabetologia 14: 397-404

18. Svenson M, Bendtzen K (1988) Inhibitor of interleukin 1 in normal human urine. Different effects on mouse thymocytes and on a murine T-cell line. Scand J Immunol 27: 593-599

19. Welsh N, Nilsson T, Hallberg A, Arkhammar P, Berggren P-O, Welsh M, Sandler S (1989) Human interleukin-1 $\beta$ stimulates insulin release by a mechanism not dependent on changes in phospholipase $\mathrm{C}$ and protein kinase $\mathrm{C}$ activities or $\mathrm{Ca}^{2+}$ handling. Acta Endocrinol (in press)

20. Eizirik DL, Sandler S, Hallberg A, Bendtzen K, Sener A, Malaisse WJ (1989) Differential sensitivity to $\beta$-cell secretagogues in cultured rat pancreatic islets exposed to human interleukin-1 $\beta$. Endocrinology: 125: 752-759

21. Keen H, Field JB, Pastan IH (1963) A simple method for in vivo metabolic studies using small volumes of tissue and medium. Metabolism 12: 143-147

22. Krebs HA, Henseleit K (1932) Untersuchungen über die Harnstoffbildung im Tierkörper. Hoppe-Seylers Z Physiol Chem 210: 33-66

23. Heding LG (1972) Determination of total serum insulin (IRI) in insulin-treated diabetic patients. Diabetologia 8: 260-266

24. Andersson A, Sandler S (1983) Viability tests of cryopreserved endocrine pancreatic cells. Cryobiology 20: 161-168

25. Borg LAH, Eide SJ, Andersson A, Hellerström C (1979) Effects in vitro of alloxan on the glucose metabolism of mouse pancreatic B-cells. Biochem J 182: 797-802

26. Wogensen L, Mandrup-Poulsen T, Markholst H, Mølvig J, Lernmark $\AA$, Holst JJ, Dinarello CA, Nerup J (1988) Interleukin-1 potentiates glucose stimulated insulin release in the isolated perfused pancreas. Acta Endocrinol 117: 302-306
27. Malaisse WJ (1983) Insulin release: the fuel concept. Diab Metab 9: $313-320$

28. Sener A, Malaisse WJ (1987) Stimulation by D-glucose of mitochondrial oxidative events in islets cells. Biochem J 246: 89-95

29. Malaisse WJ, Sener A (1988) Hexose metabolism in pancreatic islets. Feedback control of D-glucose oxidation by functional events. Biochim Biophys Acta 971: 246-254

30. Zawalich WS, Zawalich KC, Rasmussen H (1989) Interleukin-1 $\alpha$ exerts glucose-dependent stimulatory and inhibitory effects on islet cell phosphoinositide hydrolysis and insulin secretion. Endocrinology 124: 2350-2357

31. Berridge MJ, Irvine RF (1984) Inositol trisphosphate, a novel second messenger in cellular signal transduction. Nature 312: 473-482

32. Sener A, Malaisse WI (1980) L-Leucine and a nonmetabolized analogue activate pancreatic islet glutamate dehydrogenase. $\mathrm{Na}$ ture 288: 187-189

33. Malaisse WJ, Hutton JC, Carpinelli AR, Herchuelz A, Sener A (1980) The stimulus secretion-coupling of amino acid-induced insulin release. Metabolism and cationic effects of leucine. Diabetes 29: $431-437$

Received: 24 April 1989

and in revised form: 5 July 1989

Dr. D. L. Eizirik

Department of Medical Cell Biology

Biomedicum, P.O. Box 571

S-75123 Uppsala

Sweden 